\author{
A.P. Galayda ${ }^{a^{*}}$, N.E. Volkova ${ }^{a}$, A. I. Dyagileva ${ }^{a}$, \\ L. Ya. Gavrilova ${ }^{a}$, V. A. Cherepanov ${ }^{a}$, P. D. Battle ${ }^{b}$ \\ ${ }^{a}$ Institute of Natural Sciences and Mathematics, Ural Federal University, \\ 19 Mira St., Ekaterinburg, 620002, Russian Federation \\ ${ }^{b}$ Inorganic Chemistry Laboratory, University of Oxford, \\ South Parks Road, Oxford OX13QR, UK \\ ${ }^{\star}$ E-mail: anastasia.galaida@urfu.ru
}

\title{
Crystal structure and properties of novel oxide $\mathrm{Sm}_{0.9} \mathrm{Ca}_{1.1} \mathrm{Fe}_{0.7} \mathrm{Co}_{0.3} \mathrm{O}_{4-\delta}$
}

$\mathrm{Sm}_{0.9} \mathrm{Ca}_{1.1} \mathrm{Fe}_{0.7} \mathrm{Co}_{0.3} \mathrm{O}_{4-\delta}$ oxide with the $\mathrm{K}_{2} \mathrm{NiF}_{4}$-type structure was prepared using a glycerin-nitrate technique. The XRD pattern of $\mathrm{Sm}_{0.9} \mathrm{Ca}_{1.1} \mathrm{Fe}_{0.7} \mathrm{Co}_{0.3} \mathrm{O}_{4-\delta}$ was refined by the Rietveld method within an orthorhombic structure (space group $B m a b)$. The electrical conductivity, Seebeck coefficient, and thermal expansion of $\mathrm{Sm}_{0.9} \mathrm{Ca}_{1.1} \mathrm{Fe}_{0.7} \mathrm{Co}_{0.3} \mathrm{O}_{4-\delta}$ were measured depending on temperature in air. The change of oxygen nonstoichiometry determined by TGA in air does not exceed 0.01. The oxygen content in $\mathrm{Sm}_{0.9} \mathrm{Ca}_{1.1} \mathrm{Fe}_{0.7} \mathrm{Co}_{0.3} \mathrm{O}_{4-\delta}$ determined by the reduction in a hydrogen flux is equal to $3.96 \pm 0.01$. The positive value of Seebeck coefficient indicates that the predominant charge carriers in the oxide studied are electron holes.

Keywords: complex oxide; Ruddlesden-Popper phase; crystal structure; oxygen nonstoichiometry, electroconductivity; thermal expansion.

Received: 13.11.2018. Accepted: 05.12.2018. Published: 31.12.2018.

(C) Galayda A. P., Volkova N. E., Dyagileva A. I., Gavrilova L. Ya., Cherepanov V. A., Battle P. D., 2018

\section{Introduction}

Complex oxides with the $\mathrm{K}_{2} \mathrm{NiF}_{4}$-type structure based on rare earth, alkaline earth and 3d-transition metals are known as materials with high mixed electronic-ionic conductivity and oxygen mobility, and also thermodynamic stability at high temperature under an oxidizing atmosphere [1-4]. For this reason, $\mathrm{K}_{2} \mathrm{NiF}_{4}$-type oxides have attracted much attention as promising SOFC cathodes [1-3], oxygen-separation membranes [5] and catalysts [6]. The crystal structure of a $\mathrm{K}_{2} \mathrm{NiF}_{4}$-type oxide is built up by alternating the perovskite layer $\left(\mathrm{ABO}_{3}\right)$ and rock salt layer (AO) [7]. Depending on the nature of the metals in the A and $\mathrm{B}$ sublattices, the crystal structure of oxides with overall composition $\mathrm{A}_{2} \mathrm{BO}_{4}$ can be described using a tetragonal (sp. gr. $I 4 / \mathrm{mmm}$ ) or orthorhombic (sp. gr. Bmab) unit cell [3-13]. Compared with Sr-substituted phases, very little is known about Ca-doped analogues with the $\mathrm{K}_{2} \mathrm{NiF}_{4}$-type structure. It has been reported previously that metastable lanthanum calcium ferrite $\mathrm{CaLaFeO}_{4-\delta}$ decomposes at $1100^{\circ} \mathrm{C}$ to lanthanum ferrite $\mathrm{LaFeO}_{3-\delta}$ and calcium oxide $\mathrm{CaO}$ [14]. One can expect that variation of the $\mathrm{Ln} / \mathrm{Ca}$ ratio and partial substitution of more electronegative $\mathrm{Co}$ for $\mathrm{Fe}$ ions 
in the B-site position will stabilize the $\mathrm{K}_{2} \mathrm{NiF}_{4}$-type structure. The present study has focused on the structure and properties of the novel $\mathrm{Sm}_{0.9} \mathrm{Ca}_{1.1} \mathrm{Fe}_{0.7} \mathrm{Co}_{0.3} \mathrm{O}_{4-\delta}$ oxide with the $\mathrm{K}_{2} \mathrm{NiF}_{4}$-type structure.

\section{Experimental}

The complex oxide was prepared using a glycerin nitrate technique. Samarium oxide $\mathrm{Sm}_{2} \mathrm{O}_{3}$ (99.99\% purity), calcium carbonate $\mathrm{CaCO}_{3}$ ("pure for analysis" grade), metallic cobalt $\mathrm{Co}$, iron oxalate $\mathrm{FeC}_{2} \mathrm{O}_{4} \cdot 2 \mathrm{H}_{2} \mathrm{O}$ ("pure for analysis" grade), nitric acid ("special purity" grade) and glycerin were used as the starting materials. Metallic cobalt was obtained by reducing cobalt oxide $\mathrm{Co}_{3} \mathrm{O}_{4}$ ("special purity" grade) in the hydrogen flow at $400-600^{\circ} \mathrm{C}$ for $6 \mathrm{~h}$. The appropriate stoichiometric amounts of starting materials were dissolved in nitric acid, and then glycerin was added to the solution. The resulting gel was dried in a porcelain cup, decomposed to the dark powder, then placed in an alumina crucible and calcined in air at $700-1000{ }^{\circ} \mathrm{C}$ for $8-10 \mathrm{~h}$. The final annealing was performed at $1100{ }^{\circ} \mathrm{C}$ in air for $120 \mathrm{~h}$ with intermediate grindings, followed by slow cooling to room temperature at a rate of $\sim 100{ }^{\circ} \mathrm{C} / \mathrm{h}$. The phase composition of the annealed samples was determined by X-ray diffraction using a Shimadzu XRD-7000 (CuKa-radiation, angle range $2 \Theta=20-90^{\circ}$, step $0.03^{\circ}, 5 \mathrm{~s} / \mathrm{step}$ ) in air. The structural parameters were refined by the Rietveld profile method using the Fullprof-2008 package. Thermogravimet- ric analysis (TGA) was carried out using an STA 409 PC instrument (Netzsch) over the temperature range $25-1100{ }^{\circ} \mathrm{C}$ in air in dynamic (heating/cooling rate $2 \mathrm{~K} / \mathrm{min}$ ) mode. The absolute values of oxygen content were determined by a reduction of the samples in a hydrogen flux inside the TGA cell at $1200^{\circ} \mathrm{C}[15]$. Thermal expansion measurements were carried out within the temperature range of $25-1100{ }^{\circ} \mathrm{C}$ in air using a dilatometer DIL 402C (Netzsch) at a heating/cooling rate of $5 \mathrm{~K} / \mathrm{min}$. The total conductivity and Seebeck coefficients of ceramic samples were measured in air by a 4-probe method with platinum electrodes. A bar-shaped sample $(3 \times 4 \times 25 \mathrm{~mm})$ for thermal expansion coefficient (TEC) and conductivity measurements was obtained by pressing powder that was mixed with 2-3 drops of ethanol using a manually-operated press. Afterwards, the samples prepared accordingly were slow heated and then sintered at $1200^{\circ} \mathrm{C}$ for $14 \mathrm{~h}$ in air followed by slow cooling (the rate of heating and cooling was $50 \mathrm{~K} / \mathrm{h}$ ). The relative density of the sample was evaluated by a comparison of measured values to those calculated from the XRD-data. The relative density was found to be $90 \%$.

\section{Results and discussion}

In contrast with previously reported $\mathrm{SmCaCoO}_{4-\delta}[10]$ and $\mathrm{LnSrFeO}_{4-\delta}(\mathrm{Ln}=\mathrm{La}$ [16], Nd [17, 18], Gd [19], Sm [13]), we have failed to synthesize samarium-calcium ferrite with an equimolar Sm/Ca-ratio at $1100{ }^{\circ} \mathrm{C}$ in air. It is known that the homogeneity range limits for such solid solu- tions depend significantly on temperature, ionic radius of dopants and oxygen partial pressure. The decrease of temperature from $1500^{\circ} \mathrm{C}$ to $1100^{\circ} \mathrm{C}$ leads to decomposition of $\mathrm{CaLaFeO}_{4-\delta}$ to $\mathrm{LaFeO}_{3-\delta}$ and $\mathrm{CaO}$ [14].

The complex oxide $\mathrm{Sm}_{0.9} \mathrm{Ca}_{1.1} \mathrm{Fe}_{0.7} \mathrm{Co}_{0.3} \mathrm{O}_{4-\delta}$ was prepared 
by a standard glycerin-nitrate technique with annealing temperature $1100{ }^{\circ} \mathrm{C}$ in air. Diffraction data for $\mathrm{Sm}_{0.9} \mathrm{Ca}_{1.1} \mathrm{Fe}_{0.7} \mathrm{Co}_{0.3} \mathrm{O}_{4-\delta}$ analyzed by the Rietveld method are shown in Fig. 1. XRD pattern of $\mathrm{Sm}_{0.9} \mathrm{Ca}_{1.1} \mathrm{Fe}_{0.7} \mathrm{Co}_{0.3} \mathrm{O}_{4-\delta}$ was indexed in the orthorhombic structure (sp. gr. Bmab).

The value of the oxygen content in $\mathrm{Sm}_{0.9} \mathrm{Ca}_{1.1} \mathrm{Fe}_{0.7} \mathrm{Co}_{0.3} \mathrm{O}_{4-\delta}$ at room temperature determined by the TGA reduction was found to be $3.96 \pm 0.01$, and is consistent with that for $\mathrm{SmCaCoO}_{4-\delta}[10]$. The TGA measurements within the temperature

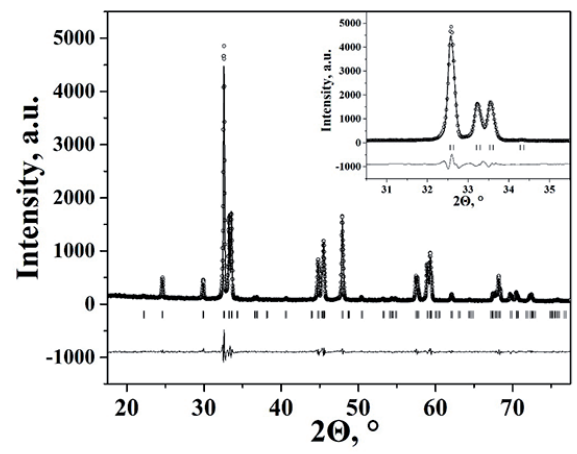

Fig. 1. Rietveld refined XRD pattern of $\mathrm{Sm}_{0.9} \mathrm{Ca}_{1.1} \mathrm{Fe}_{0.7} \mathrm{Co}_{0.3} \mathrm{O}_{4-\delta}$. Circles are the experimental XRD data, upper continuous line is the calculated profile, lower continuous line is the difference plot, vertical lines are indicating the Bragg positions

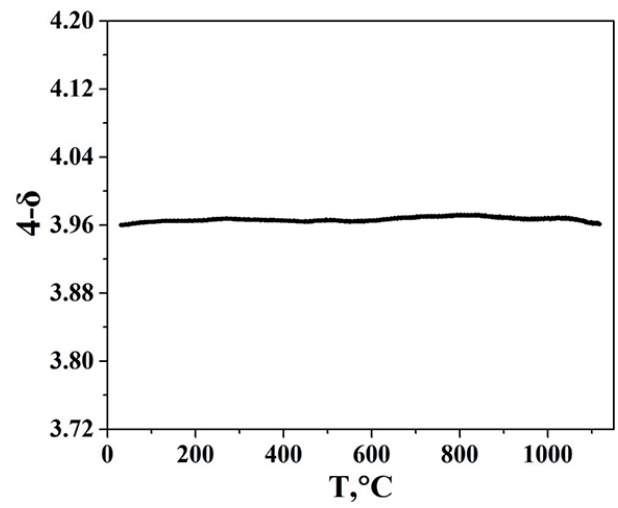

Fig. 2. Oxygen content, $4-\delta$, in $\mathrm{Sm}_{0.9} \mathrm{Ca}_{1.1} \mathrm{Fe}_{0.7} \mathrm{Co}_{0.3} \mathrm{O}_{4-\delta}$ as a function of temperature in air range of $25-1100{ }^{\circ} \mathrm{C}$ in air revealed a small change in oxygen content, $4-\delta$, that is less than 0.01 (Fig. 2).

The temperature dependence of the thermal expansion in air for $\mathrm{Sm}_{0.9} \mathrm{Ca}_{1.1} \mathrm{Fe}_{0.7} \mathrm{Co}_{0.3} \mathrm{O}_{4-\delta}$ is given in Fig. 3 in comparison with $\mathrm{SmCaCoO}_{4-\delta}[10]$.

As can be seen, the shape of the measured dependence is non-linear. Since this phenomenon cannot be explained by a noticeable oxygen exchange, we suggest that the non-linearity of the dilatometric plot is mainly associated with redistribution of electron density between $\mathrm{Co}$ and $\mathrm{Fe}$ and/or changes in Co spin states with the temperature. Similar behavior was observed in $\mathrm{SmFe}_{1-x} \mathrm{Co}_{x} \mathrm{O}_{3-\delta}(x=0.2$, $0.5,0.8)$ [10]. However, additional research is needed to clarify this behavior. The dependence of $\Delta L / L=f(T)$ has been described by two linear equations in the temperature ranges of $25-400{ }^{\circ} \mathrm{C}$ and $730-1000{ }^{\circ} \mathrm{C}$. Low- and high-temperature TEC values for $\mathrm{Sm}_{0.9} \mathrm{Ca}_{1.1} \mathrm{Fe}_{0.7} \mathrm{Co}_{0.3} \mathrm{O}_{4-\delta}$ in comparison with those of $\mathrm{SmCaCoO}_{4-\delta}$ and most common SOFC electrolytes are listed in Table 1. The decrease in the TEC value with the increase of iron content can be explained by the higher bond energy

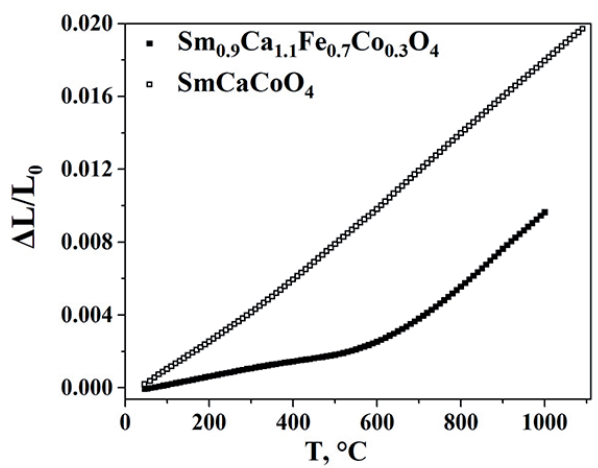

Fig. 3. Thermal expansion of the

$\mathrm{Sm}_{0.9} \mathrm{Ca}_{1.1} \mathrm{Fe}_{0.7} \mathrm{Co}_{0.3} \mathrm{O}_{4-\delta}$ and $\mathrm{SmCaCoO}_{4-\delta}[10]$ ceramics in air 
The average thermal expansion coefficients for $\mathrm{Sm}_{0.9} \mathrm{Ca}_{1.1} \mathrm{Fe}_{0.7} \mathrm{Co}_{0.3} \mathrm{O}_{4-\delta}, \mathrm{SmCaCoO}_{4-\delta}[10]$ and SOFC electrolytes $\mathrm{Zr}_{0.85} \mathrm{Y}_{0.15} \mathrm{O}_{2-\delta}$ [22] and $\mathrm{Ce}_{0.8} \mathrm{Sm}_{0.2} \mathrm{O}_{2-\delta}$ [23] in air

\begin{tabular}{c|c|c}
\hline Composition & Temperature range, ${ }^{\circ} \mathrm{C}$ & TEC $\times 10^{6}, \mathrm{~K}^{-1}$ \\
\hline \multirow{2}{*}{$\mathrm{Sm}_{0.9} \mathrm{Ca}_{1.1} \mathrm{Fe}_{0.7} \mathrm{Co}_{0.3} \mathrm{O}_{4-\delta}$} & $25-400$ & 4.4 \\
\cline { 2 - 3 } & $730-1000$ & 20.2 \\
\hline \multirow{2}{*}{$\mathrm{SmCaCoO}_{4-\delta}[10]$} & $25-580$ & 17.7 \\
\cline { 2 - 3 } & $580-1100$ & 20.2 \\
\hline $\mathrm{Zr}_{0.85} \mathrm{Y}_{0.15} \mathrm{O}_{2-\delta}[22]$ & $30-1000$ & 10.9 \\
\hline $\mathrm{Ce}_{0.8} \mathrm{Sm}_{0.2} \mathrm{O}_{2-\delta}[23]$ & $30-1000$ & 12.5
\end{tabular}

for $\mathrm{Fe}-\mathrm{O}(409 \mathrm{~kJ} / \mathrm{mol})$ compared to $\mathrm{Co}-\mathrm{O}$ (368 kJ/mol) [20].

The total conductivity of $\mathrm{Sm}_{0.9} \mathrm{Ca}_{1.1} \mathrm{Fe}_{0.7} \mathrm{Co}_{0.3} \mathrm{O}_{4-\delta}$ versus temperature is shown in Fig. 4.

The c o n d u c t i vity of $\mathrm{Sm}_{0.9} \mathrm{Ca}_{1.1} \mathrm{Fe}_{0.7} \mathrm{Co}_{0.3} \mathrm{O}_{4-\delta}$ monotonously increases with temperature up to $23 \mathrm{~S} / \mathrm{cm}$ at $1100{ }^{\circ} \mathrm{C}$. In contrast, the Seebeck coefficient decreases with temperature. The positive value of the Seebeck coefficient (see Fig. 5) indicates that electron holes are the predominant charge carriers in the oxide studied. The conductivity activation energies calculated from two linear segments of Arrhenius plot (see insert in Fig. 4) are equal to $0.193 \mathrm{eV}$ and $0.283 \mathrm{eV}$ in the temperature ranges $50-250^{\circ} \mathrm{C}$ and $300-$ $1100^{\circ} \mathrm{C}$, respectively. Both values are typical for a hopping conduction mechanism.

A comparison of the temperature dependences of the total conductivity of $\mathrm{Sm}_{0.9} \mathrm{Ca}_{1.1} \mathrm{Fe}_{0.7} \mathrm{Co}_{0.3} \mathrm{O}_{4-\delta}$ and $\mathrm{SmCaCoO}_{4-\delta}$ [10] (see Fig. 4) visually shows that they coincide in practical term up to $600^{\circ} \mathrm{C}$ and the conductivityhas thermally activated character for both oxides. A strong increase in the conductivity of $\mathrm{SmCaCoO}_{4-\delta}$ above $600{ }^{\circ} \mathrm{C}$ can be explained by the pronounced charge disproportionation process at higher temperatures:

$$
2 \mathrm{Co}_{\mathrm{Co}}^{\times} \leftrightarrow \mathrm{Co}_{\mathrm{Co}}^{\circ}+\mathrm{Co}_{\mathrm{Co}}^{\prime}
$$

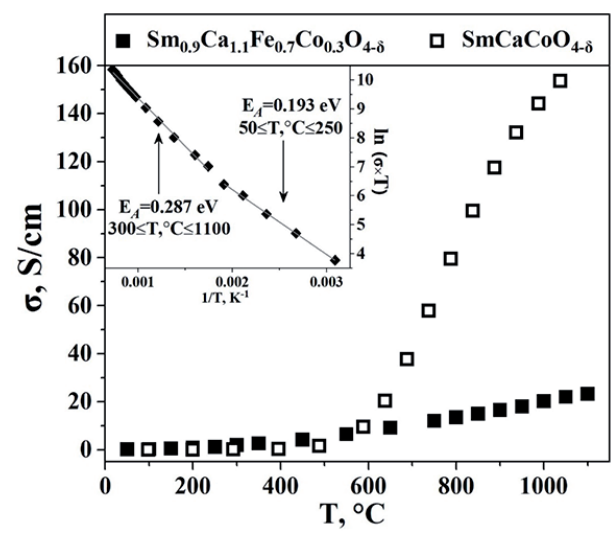

Fig. 4. Total conductivity of $\mathrm{Sm}_{0.9} \mathrm{Ca}_{1.1} \mathrm{Fe}_{0.7} \mathrm{Co}_{0.3} \mathrm{O}_{4-\delta}$ and $\mathrm{SmCaCoO}_{4-\delta}$ [10] versus temperature in air.

The insert shows the Arrhenius plot for $\mathrm{Sm}_{0.9} \mathrm{Ca}_{1.1} \mathrm{Fe}_{0.7} \mathrm{Co}_{0.3} \mathrm{O}_{4-\delta}$

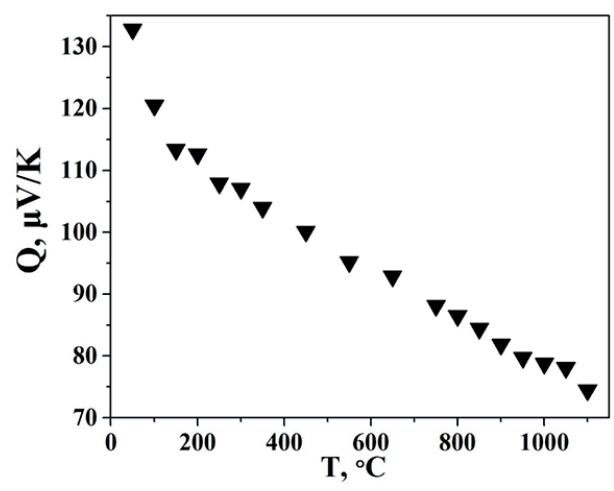

Fig. 5. Seebeck coefficient for $\mathrm{Sm}_{0.9} \mathrm{Ca}_{1.1} \mathrm{Fe}_{0.7} \mathrm{Co}_{0.3} \mathrm{O}_{4-\delta}$ vs. temperature in air 
In contrast, simultaneous presence of $\mathrm{Co}$ and $\mathrm{Fe}$ at the B-sites suppress disproportionation of iron and cobalt by the following process:

$$
\mathrm{Fe}_{\mathrm{Fe}}^{\times}+\mathrm{Co}_{\mathrm{Fe}}^{\times} \leftrightarrow \mathrm{Fe}_{\mathrm{Fe}}^{\circ}+\mathrm{Co}_{\mathrm{Fe}}^{\prime},
$$

where iron seems to be a hole trap [21].

\section{Conclusions}

Single-phase $\mathrm{Sm}_{0.9} \mathrm{Ca}_{1.1} \mathrm{Fe}_{0.7} \mathrm{Co}_{0.3} \mathrm{O}_{4-\delta}$ was successfully synthesized by a glycerin nitrate technique. The structural parameters of the oxide prepared were refined by the Rietveld method. The oxygen content, $4-\delta$, at room temperature was found to be $3.96 \pm 0.01$ and its decrease with temperature does not exceeded 0.01 .
The lower value of the total conductivity of $\mathrm{Sm}_{0.9} \mathrm{Ca}_{1.1} \mathrm{Fe}_{0.7} \mathrm{Co}_{0.3} \mathrm{O}_{4-\delta}$ compared to that of $\mathrm{SmCaCoO}_{4-\delta}$ was explained in terms of an electronic exchange process. The Seebeck coefficient of $\mathrm{Sm}_{0.9} \mathrm{Ca}_{1.1} \mathrm{Fe}_{0.7} \mathrm{Co}_{0.3} \mathrm{O}_{4-\delta}$ was shown to be positive over the entire temperature range investigated, indicating predominantly p-type conductivity.

\section{Acknowledgements}

This work was supported in parts by Act 211 Government of the Russian Federation, agreement 02.A03.21.0006.

\section{References}

1. Istomin SYa, Antipov EV. Cathode materials based on perovskite-like transition metal oxides for intermediate temperature solid oxide fuel cells. Russ Chem Rev. 2013;82(7):686-700. DOI: 10.1070/RC2013v082n07ABEH004390.

2. Dailly J, Fourcade S, Largeteau A, Mauvy F, Grenier JC, Marrony M. Perovskite and $\mathrm{A}_{2} \mathrm{MO}_{4}$-type oxides as new cathode materials for protonic solid oxide fuel cells. Electrochim Acta. 2010;55(20):5847-53. DOI: 10.1016/j.electacta.2010.05.034.

3. Zhao F, Wang $\mathrm{X}$, Wang Z, Peng R, Xia C. $\mathrm{K}_{2} \mathrm{NiF}_{4}$ type $\mathrm{La}_{2-\mathrm{x}} \mathrm{Sr}_{\mathrm{x}} \mathrm{Co}_{0.8} \mathrm{Ni}_{0.2} \mathrm{O}_{4+\delta}$ as the cathodes for solid oxide fuel cells. Solid State Ionics. 2008;179:1450-3. DOI: 10.1016/j. ssi.2008.06.019.

4. Daroukh MAl, Vashook VV, Ullmann H, Tietz F, Arual Raj I. Oxides of the $\mathrm{AMO}_{3}$ and $\mathrm{A}_{2} \mathrm{MO}_{4}$-type: structural stability, electrical conductivity and thermal expansion. Solid State Ionics. 2003;158:141-50. DOI: 10.1016/S0167-2738(02)00773-7.

5. Vashook VV, Yushkevich II, Kokhanovsky LV, Makhnach LV, Tolochko SP, Kononyuk IF, Ullmann H, Altenburg H. Composition and conductivity of some nickelates. Solid State Ionics. 1999;119:23-30. DOI: 10.1016/S0167-2738(98)00478-0.

6. Ling Z, Xuezhong W, Cunzhen L. Catalytic combustion of diesel soot over $\mathrm{K}_{2} \mathrm{NiF}_{4}$-type oxides $\mathrm{La}_{2-\mathrm{x}} \mathrm{K}_{\mathrm{x}} \mathrm{CuO}_{4}$. J Rare Earths. 2008.;26(2):254-7. DOI: 10.1016/S10020721(08)60076-9.

7. Skinner SJ. Characterisation of $\mathrm{La}_{2} \mathrm{NiO}_{4+\delta}$ using in-situ high temperature neutron powder diffraction. Solid State Sci. 2003;5:419-26. DOI: 10.1016/S12932558(03)00050-5

8. Taguchi H, Nakade K, Hirota K. Synthesis and characterization of $\mathrm{K}_{2} \mathrm{NiF}_{4}$-type $\mathrm{CaLnCoO}_{4}(\mathrm{Ln}=\mathrm{Sm}$ and Gd). Mater Res Bull. 2007;42:649-56. DOI: 10.1016/j. materresbull.2006.08.004. 
9. Taguchi H, Kido H, Tabata T. Relationship between crystal structure and electrical property of $\mathrm{K}_{2} \mathrm{NiF}_{4}$-type $\left(\mathrm{Ca}_{1-\mathrm{x}} \mathrm{Nd}_{1+\mathrm{x}}\right) \mathrm{CoO}_{4-\mathrm{d}}$. Physica B. 2004;344:271-7. DOI: 10.1016/j.physb.2003.09.270.

10. Galayda AP, Volkova NE, Gavrilova LYa, Balymov KG, Cherepanov VA. Phase equilibria, structure and properties of intermediate phases in the $\mathrm{Sm}_{2} \mathrm{O}_{3}-\mathrm{Fe}_{2} \mathrm{O}_{3}-\mathrm{CoO}$ and $\mathrm{Sm}_{2} \mathrm{O}_{3}-\mathrm{CaO}-\mathrm{CoO}$ systems. J Alloys Compd. 2017;718:288-97. DOI: 10.1016/j. jallcom.2017.05.044.

11. Romero de Paz J, Fernández-Díaz MT, Hernández Velasco J, Sáez Puche R, Martinez JL. Crystal and Magnetic Structure of $\mathrm{PrCaCrO}_{4}$. J Solid State Chem. 1999;142(1):29-32. DOI: 10.1006/jssc.1998.7973.

12. Thorogood GJ, Orain P-Y, Ouvry M, Piriou B, Tedesco T, Wallwork KS, Herrmann J, James M. Structure, crystal chemistry and magnetism of rare earth calcium-doped cobaltates: $\mathrm{Ln}_{2-\mathrm{x}} \mathrm{Ca}_{\mathrm{x}} \mathrm{CoO}_{4+\delta}(\mathrm{Ln}=\mathrm{Pr}, \mathrm{Nd}, \mathrm{Sm}, \mathrm{Eu}, \mathrm{Gd})$. Solid State Sci. 2011;13:2113-23. DOI: 10.1016/j.solidstatesciences.2011.08.008.

13. Volkova NE, Maklakova AV, Gavrilova LYa, Cherepanov VA. Phase equilibria, crystal structure, and properties of intermediate oxides in the $\mathrm{Sm}_{2} \mathrm{O}_{3}-\mathrm{SrO}-\mathrm{CoO}$ system. Eur J Inorg Chem. 2017:3285-92. DOI: 10.1002/ejic.201700321.

14. Nguyen-Trut-Dinh MM, Vlasse M, Perrin M, Le Flem G. Un oxide magnetique bidimensionnel: $\mathrm{CaLaFeO}_{4}$. J Solid State Chem. 1980;32:1-8. DOI: 10.1016/00224596(80)90262-5.

15. Volkova NE, Gavrilova LYa, Cherepanov VA, Aksenova TV, Kolotygin VA, Kharton VV. Synthesis, crystal structure and properties of $\mathrm{SmBaCo}_{2-\mathrm{x}} \mathrm{Fe}_{\mathrm{x}} \mathrm{O}_{5+\delta}$.J Solid State Chem. 2013:204;219-23. DOI: 10.1016/j.jssc.2013.06.001.

16. Jennings AJ, Skinner SJ, Helgason Ö. Structural properties of $\mathrm{La}_{\mathrm{x}} \mathrm{Sr}_{2-\mathrm{x}} \mathrm{FeO}_{4 \pm d}$ at high temperature and under reducing conditions. J Solid State Chem. 2003;175:207-17. DOI: 10.1016/S0022-4596(03)00248-2.

17. Ki-Woog S, Ki-Tae L. Characterization of $\mathrm{NdSrCo}_{1-\mathrm{x}} \mathrm{Fe}_{\mathrm{x}} \mathrm{O}_{4+\mathrm{d}}(0 \leq \mathrm{x} \leq 1.0)$ intergrowth oxide cathode materials for intermediate temperature solid oxide fuel cells. Ceram Int. 2011;37:573-7. DOI: 10.1016/j.ceramint.2010.10.004.

18. Aksenova TV, Vakhromeeva AE, Elkalashy ShI, Urusova AS, Cherepanov VA. Phase equilibria, crystal structure, oxygen nonstoichiometry and thermal expansion of complex oxides in the $\mathrm{Nd}_{2} \mathrm{O}_{3}-\mathrm{SrO}-\mathrm{Fe}_{2} \mathrm{O}_{3}$ system. J Solid State Chem. 2017;251:70-8. DOI: $10.1016 /$ j.jssc.2017.04.015.

19. Singh S, Singh D. Effect of increasing Sr content on structural and physical properties of $\mathrm{K}_{2} \mathrm{NiF}_{4}$-type phase $\mathrm{GdSrFeO}_{4}$. Ceram Int. 2017;43:3369-76. DOI: 10.1016/j. ceramint.2016.11.182.

20. Cottrell TL. The Strengths of Chemical Bonds. 2nd ed. London: Butterworth; 1958. $317 \mathrm{p}$.

21. Tai L-W, Nasrallah MM, Anderson HU, Sparlin DM, Sehlin SR. Structure and electrical properties of $\mathrm{La}_{1-\mathrm{x}} \mathrm{Sr}_{\mathrm{x}} \mathrm{Co}_{1-\mathrm{y}} \mathrm{Fe}_{\mathrm{y}} \mathrm{O}_{3}$. Part 1 . The system $\mathrm{La}_{0.8} \mathrm{Sr}_{0.2} \mathrm{Co}_{1-y} \mathrm{Fe}_{\mathrm{y}} \mathrm{O}_{3}$. Solid State Ionics. 1995;76:259-71. DOI: 10.1016/0167-2738(94)00244-m.

22. Tsipis EV, Kharton VV. Electrode materials and mechanisms in solid oxide fuel cells: brief review. J Solid State Electrochem. 2008;12(11):1367-91. DOI: 10.1007/s10008-008-0611-6. 
23. Pikalova EYu, Murashkina AA, Maragou VI, Demin AK, Strekalovsky VN, Tsiakaras $\mathrm{PE}$. $\mathrm{CeO}_{2}$ based materials doped with lanthanides for applications in intermediate temperature electrochemical devices. Int J Hydrogen Energy. 2011;36:6175-83. DOI: 10.1016/j.ijhydene.2011.01.132. 